\title{
$\mathrm{M}[\mathrm{R} S \mathrm{~S}$
}

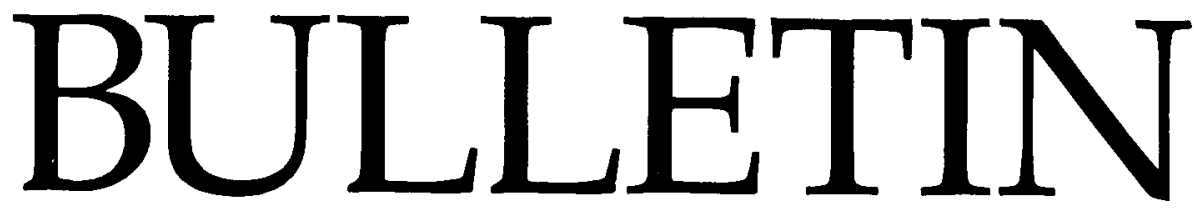

Materials Research Society Vol. VIII No. 6 November/December 1983

\section{REPORT FROM BOSTON}

\section{In This Special Edition, Summaries Of The Symposia \\ And The Full Remarks of the Plenary And Von Hippel Speakers}

No one who attended the Boston Meeting is likely to forget Arthur von Hippel's anecdote about the great Norwegian Victor Goldschmidt cultivating the neighborhood squirrels and naming them after his scientific enemies. In the two sessions that annually convene the entirety of our membership-the Plenary and Von Hippel Award Sessions-we had the unique opportunity to reminisce about the formative years of materials science with one of its foremost practitioners; to share the concerns and vision of one of Britain's most esteemed scientists-statesmen; to probe the responsibilities and guiding ideals of national and state political and scientific leaders.

The 1983 Plenary and Von Hippel Award sessions were extraordinary. In the former, "The Role of Government, Industries, and Universities in the Support and the "Performance of Materials Research" was examined in depth by George A. Keyworth II, Science Advisor to the President and Director of the Office of Science and Technology Policy; Donald S. Beilman, President of the Microelectronics Center of North Carolina, and Michael S. Dukakis, Governor of the Commonwealth of Massachusetts. In carefully coordinated remarks they defined the issues that confront policy makers in formulating programs that foster effective scientific research and technological innovation, and the roles each sector must play in achieving the most effective results.

In the latter session, Oxford University Professor Sir Peter B. Hirsch, F.R.S., received the Materials Research Society's highest accolade, the Arthur Von Hippel Award; and the renowned scientist for whom the award is named was present to congratulate his successor to the prize. Sir Peter, who also is Chairman of the United Kingdom Atomic Energy Authority, challenged materials scientists to be mindful that they create what he called an "enabling technology" which permits engineers to turn design into hardware, and urged them to work closely with their engineering colleagues to foster this mutual concern. At the same time, he pointed out that the origin of technological change can usually be traced to fundamental, speculative

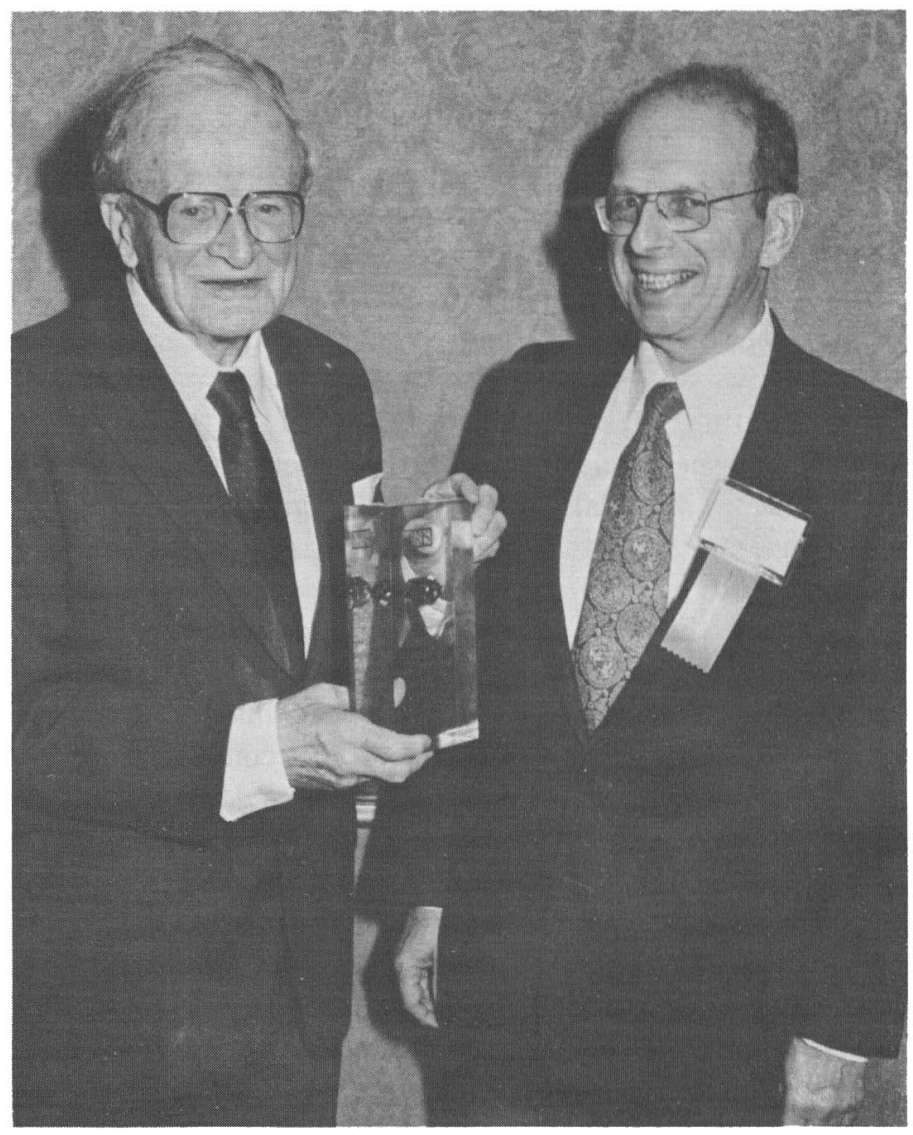

ARTHUR VON HIPPEL (left) and PETER HIRSCH

work, which must not be neglected despite budgetary constraints.

These sessions highlighted a Boston Meeting unprecedented in its size, scope, and level of achievement. Attendance topped 1,600, far exceeding even the most optimistic forecast; a record number of papers and posters were accepted, and a record number of Proceedings volumes will appear as a result of the conference. Many of the technical meetings are reported at length in these pages. 